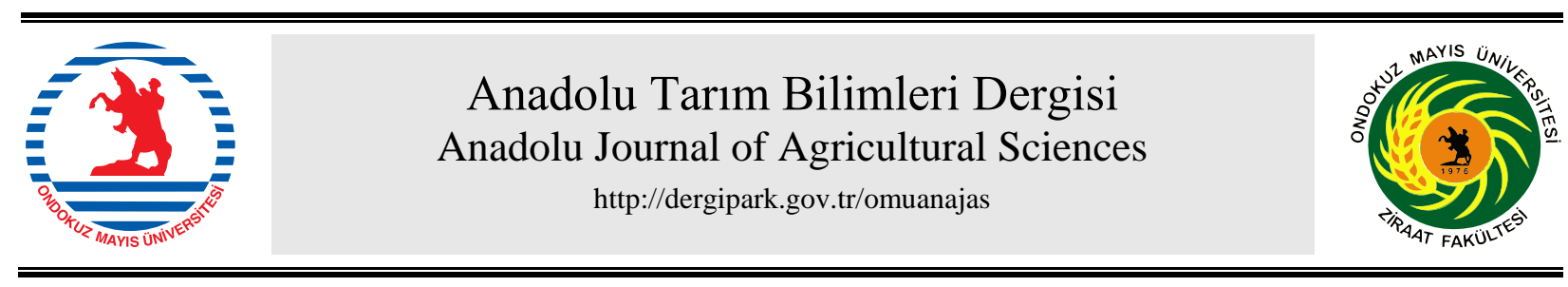

Araştırma/Research

Anadolu Tarım Bilim. Derg./Anadolu J Agr Sci, 33 (2018)

ISSN: 1308-8750 (Print) 1308-8769 (Online) doi:10.7161/omuanajas.391372

\title{
Ahmetli ve Turgutlu (Manisa) ilçelerindeki bağlarda salkım güvesi [Lobesia botrana den. \& schiff. (lep.: tortricidae)]'nin popülasyon değişimi ve bulaşıklık oranının saptanmas1
}

\author{
Fethi Güleç ${ }^{\mathrm{a}}$, Levent Ünlü*b \\ ${ }^{a}$ Turgutlu Gıda Tarım Ve Hayvancllık İlçe Müdürlüğü, Manisa. \\ ${ }^{b}$ Selçuk Üniversitesi, Ziraat Fakültesi, Bitki Koruma Bölümü, Konya \\ *Sorumlu yazar/corresponding author: ulevent @ selcuk.edu.tr
}

Geliş/Received 07/02/2018～Kabul/Accepted 02/10/2018

\begin{abstract}
ÖZET
Ahmetli ve Turgutlu (Manisa) ilçelerinde belirlenen sekiz adet bağ alanında, Yuvarlak Çekirdeksiz üzüm çeşidinde Salkım güvesi (Lobesia botrana Den. \& Schiff.) (Lep.: Tortricidae)'nin popülasyon gelişimini ve bulaşıklık oranını saptamak amacıyla 2012-2013 yıllarında çalışmalar yürütülmüştür. Zararlının popülasyon gelişimini belirlemede eşey feromon tuzakları her köye bir adet olacak şekilde kullanılmıştır. Lobesia botrana'nın bulaşıklık oranını belirlemek için, her bağda dört farklı sıra üzerinde rastgele seçilen 100 adet salkım kontrol edilerek bulaşıklık oranı tespit edilmiştir. Salkım güvesi her iki ilçede, yakalanan ergin sayıları bakımından hasat tarihine kadar üç, hasattan sonra da bir olmak üzere toplam dört tepe noktası oluşturmuştur. Hasat dönemine kadar tuzaklarda haftalık en fazla ergin, 2012 y1lında Ahmetli'de Karaköy (394 adet) ve Turgutlu'da Derbent beldesi (439 adet)'nde 23 Ağustos tarihinde, 2013 y1lında Ahmetli'de Ataköy (306 adet) ve Turgutlu'da Sarıbey (345 adet) köyünde 22 Ağustos tarihinde yakalanmıştır. Hasat döneminden sonra ise tuzaklarda haftalık en fazla ergin, 2012 yılında Ahmetli'de Gökkaya beldesi (477 adet) ve Turgutlu'da Akçapınar (504 adet) köyünde 30 Ağustos tarihinde, 2013 yılında Ahmetli'de Ataköy (426 adet) ve Turgutlu'da Sarıbey (647 adet) köyünde 12 Eylül tarihinde yakalanmıştır. Lobesia botrana'nın en yüksek bulaşıklık oranları; 2012 yılında Ahmetli'de Gökkaya beldesi ile Karaköy'de \% 46, Turgutlu'da Sarıbey köyünde \% 41 olarak 23 Ağustos tarihinde, 2013 yılında ise Ahmetli'de Gökkaya beldesinde \% 58 ve Turgutlu'da Sarıbey köyünde \% 62 olarak 22 Ağustos tarihinde tespit edilmiştir. Üreticilerimizin, Salkım güvesi ile mücadeleye karar verirken mutlak surette feromon tuzaklarında ergin sayısı başta olmak üzere diğer bazı kriterleri dikkate almaları gerekmektedir.
\end{abstract}

Determination of population development and infestation ratio of Lobesia botrana den. \& schiff. (lep.: tortricidae) in Ahmetli and Turgutlu (Manisa) districts

\section{ABSTRACT}

The studies were conducted between 2012 and 2013 in order to determine the population development and contamination rate of European Grapevine moth (Lobesia botrana Den. \& Schiff.) (Lep.: Tortricidae) on ball seedless grape variety in eight varieties of vineyards identified in Ahmetli and Turgutlu (Manisa) between 2012 and 2013. The pheromone traps were used as one unit for each village to determine the population development of the pest. To determine the infestation ratio of Lobesia botrana, a random sample of 100 bunches of grapes from four different rows in each vineyard was checked. In terms of the number of adults captured, vine moth created a total of four peaks of abundance, three of which were until the date of harvest and one was after the harvest in both towns. Until the harvest period, the maximum number of adults per week was caught in Ahmetli-Karaköy (394 pieces) and Turgutlu-Derbent (439 pieces) on August 23rd, 2012, and Ahmetli-Ataköy (306 pieces) and Turgutlu-Sarıbey ( 345 pieces) on 22nd August, 2013. After the harvest period, the maximum number of adult captured was obtained in Ahmetli-Gökkaya (477 pieces) and Turgutlu-Akçapınar (504 pieces), on August 30th, 2012 and Ahmetli-Ataköy (426 pieces) and Turgutlu Sarıbey (647 pieces) on September 12th, 2013. The highest rate of infestation of L. botrana was found in Ahmetli-Gökkaya and Karaköy,

Anahtar Sözcükler: Salkım Güvesi Feromon Popülasyon Gelişimi Bulaşıklık Oranı Bağ

Keywords: European grapevine moth Pheromone Population development Infestation rate Vineyard 
which was $46 \%$, and in Turgutlu-Sarıbey, which was $41 \%$, on August 23rd, 2012, whereas it was found in Ahmetli-Gökkaya as $58 \%$ and Turgutlu-Saribey as $62 \%$ on August 22nd, 2013. When our producers decide to control against European Grapevine moth, they need to take into account some criteria, especially the number of adults in the pheromone traps.

\section{Giriş}

Asma, Rhamnales takımında yer alıp, Vitaceae familyasına ait bir kültür bitkisidir. Bu familyanın 12 cinsi ve yaklaşı 700 türü bulunmaktadır (Winkler ve ark., 1974; Anteliff, 1992). Üzüm, yüksek şeker içeriğinden dolayı, kalori değeri yüksek bir besin maddesidir. Ayrıca, mineral maddelerden kalsiyum, potasyum, sodyum ve demir yönünden zengin olduğu gibi, baz1 vitaminler (A, B1, B2, Niacin, ve C vitaminleri) yönünden de önemli bir kaynak olarak kabul edilmektedir. Ancak üzümün beslenme değerini oluşturan maddelerin niteliği ve miktarı, taze veya işleme sonucunda dönüştüğü mamul ürüne bağlı olarak değişmektedir. Yaş üzüm ile karşılaştırıldıklarında, kuru üzüm ve pekmez, daha az su içerdiklerinden daha yüksek kalorili, demir ve kalsiyum mineralleri bakımından daha zengindirler. Kurutma ve üzüm suyuna işleme sırasında, özellikle $A$ ve $C$ vitaminlerinde önemli kayıplar meydana gelmektedir (Bulduk, 1986; Westwood, 1993).

Üzüm, dünyada oldukça geniş alana yayılan meyve türlerinden biridir. Dünya yaş üzüm üretimi 2011 yılı itibariyle 7096741 hektar alanda gerçekleştirilmekte olup, üretim miktarı yıllık 77438929 ton civarındadır. Sahip oldukları bağ alanları bakımından dünyanın ilk beş üretici ülkesi İspanya, Fransa, İtalya, Çin ve Türkiye'dir. Ülkeler üzüm üretim miktarları açısından değerlendirildiğinde Çin, İtalya, ABD, Fransa, İspanya ve Türkiye olarak sıralanmaktadır (Anonim, 2016).

Türkiye'de 2016 yılı verilerine göre; 435.227 hektar alanda 4.000 .000 ton yaş üzüm üretilmiştir (Anonim, 2016). Ege Bölgesi'nde bağcıllk diğer tarımsal faaliyetlerin başında gelmektedir. Özellikle Sultani ve Yuvarlak çekirdeksiz üzüm çeşitleri bölge için en fazla öneme sahip olup, Manisa ve İzmir illerinde diğer üzüm çeşitlerine çok az rastlanılmaktadır (Kacar, 1982). Ege Bölgesi bağcılık açısından Türkiye'nin en önemli bölgesi olup, bağ alanlarının \% 33.68'i (140.444 hektar), üretiminde \% 53.27'si (2237356 ton) bu bölgededir (Anonim, 2017). Ege Bölgesi'nde yetiştirilen çekirdeksiz üzümlerin \% 90'ı Yuvarlak, \% 10'u Sultani'dir (İlter, 1975). Manisa ilinde 2013 y1lı verilerine göre 75400 hektar bağ alanı vardır. Bunun 71601 hektarı çekirdeksiz, 2.897 hektarı çekirdekli, 902 hektarı da şaraplık olarak yetiştirilmektedir. Bu alanlarda 1.163.899 ton yaş üzüm üretilmektedir (Anonim, 2013b).

Ahmetli ve Turgutlu ilçelerinde 2012 y11 istatistiklerine göre sirasiyla 5050 ve 8149 hektar bağ alanı bulunmaktadır. $\mathrm{Bu}$ bağ alanlarında üretim miktarları 2012 yılı verilerine göre Ahmetli ve Turgutlu ilçelerinde sırasıyla 126137 ve 154848 ton olarak gerçekleşmiştir (Anonim, 2012).
Ülkemizde çekirdeksiz kuru üzüm üretimi, Ege Bölgesi'nde özellikle Manisa, Turgutlu, Salihli, Akhisar, Menemen, Kemalpaşa, Çal ve Çivril'de yoğunlaşmıştır. Türkiye, yaş üzüm üreticiliğindeki güçlü konumuna paralel olarak, dünya çekirdeksiz kuru üzüm üretiminde de önemli bir yere sahiptir (Anonim, 2013a).

Salkım güvesi (Lobesia botrana Den. \& Schiff.) doğrudan üründe zarar oluşturması nedeniyle hem dünyada hem de ülkemizde bağların ana zararlısıdır (Kısakürek, 1972; Kacar, 1982; Ataç ve ark., 1990; Altındişli ve Kısmalı, 1996). Salkım güvesi larvaları bağlarda tomurcuk, çiçek, koruk ve olgun tanelerde beslenerek zarar oluşturur. Tomurcuk ve çiçek devresinde, larva salgıladığı ipliklerle tomurcuk ve çiçekleri birbirine bağlamaktadır. Zarara uğrayan tomurcuk ve çiçekler dökülür ve bunun sonucunda seyrek taneli salkımlar oluşur. Koruk döneminde taneleri kemirmek, delmek ve bir taneden diğerine geçmek suretiyle zarar oluşturur. Olgun tane döneminde ise birden çok taneye girip beslenmesi sonucu şekerli sıvıların akmasına ve bu sıvıların üzerinde saprofit fungusların çoğalmasına ve sonunda salkımın çürümesine neden olmaktadır (İyriboz, 1938; Sipahi, 1956; Anonim, 1999; Anonim, 2008).

$\mathrm{Bu}$ çalışmada, Manisa ilinin Ahmetli ve Turgutlu ilçelerinde, Yuvarlak çekirdeksiz üzüm bağlarında, L. botrana'nın eşeysel çekici feromon tuzakları ile ergin popülasyon gelişiminin ve bulaşıklık oranının belirlenmesi amaçlanmıştır.

\section{Materyal ve Yöntem}

\subsection{Materyal}

$\mathrm{Bu}$ çalışma, Manisa ilinin çekirdeksiz üzüm yetiştirme potansiyeli ve sahip olduğu bağ alanları göz önünde bulundurularak, Ahmetli ve Turgutlu ilçelerinde 2012-2013 yıllarında yürütülmüştür. Çalışmanın ana materyalini; Salkım güvesi ile Yuvarlak çekirdeksiz üzüm bağları oluşturmuştur. Ayrıca diğer materyal olarak sıcaklık verilerinin alındığı iklim istasyonu, eşeysel çekici tuzaklar ile feromon kapsüller kullanılmıştır.

Çalışmaların yürütüldüğü bağ alanlarının birbirinden belirli uzaklıkta olmasına dikkat edilmiştir. İki bağ arası çok yakın olan alanlar seçilmemiştir. Ahmetli ve Turgutlu ilçelerinde, çalışmanın yürütüldüğü köy ve beldelere ait toplam bağ alanları, bağlarının bulunduğu yerlerin koordinatları ve bu bağların yaşları ile ilgili bilgiler Çizelge 1'de verilmiştir.

Söz konusu bă alanlarının tamamı "Yuvarlak Çekirdeksiz" üzüm çeşidi ile tesis edilmiş olup, elde edilen üzümler kurutmalık olarak değerlendirilmektedir. 
Çizelge 1. Ahmetli ve Turgutlu ilçelerindeki deneme bağlarının özellikleri

\begin{tabular}{|c|c|c|c|c|c|c|}
\hline \multirow[t]{2}{*}{ İlçe } & \multirow[t]{2}{*}{ Köy/Belde } & \multicolumn{2}{|c|}{ Koordinat } & \multirow{2}{*}{$\begin{array}{c}\text { Toplam bağ alanı } \\
\text { (da) }\end{array}$} & \multirow{2}{*}{$\begin{array}{c}\text { Çalışma alanı } \\
\text { (da) }\end{array}$} & \multirow{2}{*}{$\begin{array}{c}\text { Bağın } \\
\text { yaş1 }\end{array}$} \\
\hline & & Kuzey & Doğu & & & \\
\hline \multirow{4}{*}{ Ahmetli } & Ataköy & $38^{\circ} 32^{\prime} 30.29^{\prime \prime}$ & $27^{\circ} 56^{\prime} 15.58^{\prime \prime}$ & 2.320 & 20 & 14 \\
\hline & Kestelli & $38^{\circ} 33^{\prime} 33.43^{\prime \prime}$ & $27^{\circ} 56^{\prime} 17.58^{\prime \prime}$ & 954 & 20 & 25 \\
\hline & Gökkaya & $38^{\circ} 29^{\prime} 50.72^{\prime \prime}$ & $27^{\circ} 52^{\prime} 43.69^{\prime \prime}$ & 6.870 & 15 & 16 \\
\hline & Karaköy & $38^{\circ} 32^{\prime 2} 21.22^{\prime \prime}$ & $27^{\circ} 52^{\prime} 39.23^{\prime \prime}$ & 2.424 & 20 & 9 \\
\hline \multirow{4}{*}{ Turgutlu } & Derbent & $38^{\circ} 31^{\prime 09.69^{\prime \prime}}$ & $27^{\circ} 47^{\prime} 58.95^{\prime \prime}$ & 4.840 & 17 & 15 \\
\hline & Sarıbey & $38^{\circ} 32^{\prime} 34.18^{\prime \prime}$ & $27^{\circ} 47^{\prime} 16.51^{\prime \prime}$ & 3.561 & 13 & 17 \\
\hline & Akçapınar & $38^{\circ} 29^{\prime} 46.02^{\prime \prime}$ & $27^{\circ} 50^{\prime} 38.52^{\prime \prime}$ & 2.741 & 15 & 20 \\
\hline & Musacalı & $38^{\circ} 33^{\prime 26.02 "}$ & $27^{\circ} 47^{\prime} 19.35^{\prime \prime}$ & 6.718 & 20 & 30 \\
\hline
\end{tabular}

edilmeye başlandığ 2012 ve 2013 yılları için sırasıyla

\subsection{Yöntem}

\subsubsection{Lobesia botrana'nın popülasyon değişiminin belirlenmesi}

Denemeler, Manisa ilinin Ahmetli ve Turgutlu ilçelerinde, her ilçede dörder adet olmak üzere toplam sekiz adet seçilen bağlarda yürütülmüştür. Çalışmalar iki yıl süresince belirlenen alanlarda devam etmiștir. Bu bağların her birine, 1 Ocak'tan itibaren günlük maksimum sicaklık toplamları (MST)'nın $1000^{\circ} \mathrm{C}^{\prime} \mathrm{ye}$ yaklaştığı tarihlerde ilk ergin çıkışları beklendiği için birer adet eşeysel çekici feromon tuzağı, salkım seviyesinde ve hakim rüzgar yönünde asılmıștır (Altındişli ve Kısmalı, 1996; Anonim, 1999; 2005; 2008).

Tuzakların bağ içinde bulundukları konum tüm alanı temsil edecek şekilde ayarlanmıștır. Tuzaklar rüzgar, yağmur, aşırı sıcaklık vb. dış etkenlerden etkilenmeyecek şekilde asılmıştır. Her tuzağa birer adet olmak üzere feromon kapsül, yapışkan yüzeye temas etmeyecek şekilde ve el değmeden yerleştirilmiştir.

Feromon kapsülleri altı haftada bir değiştirilmiştir. Deneme bağlarında eșeysel çekici tuzaklar her hafta düzenli olarak kontrol edilmiş, tuzaklarda yakalanan erginler bir pens yardımı ile sayılarak kaydedilmiş ve tuzaklar temizlenmiştir.

\subsubsection{Lobesia botrana'nın bulaşıklık oranının belirlenmesi}

Lobesia botrana'nın bulaşıklık oranını belirlemek için, Ahmetli ve Turgutlu ilçelerinde belirlenen her bağda, dört farklı bağ sırası üzerinde rastgele seçilen omca ve salkımlarda gözlemler yapılmıştır. Her defasında tesadüfi olarak seçilen 100 salkım kontrol edilmiştir. Yapılan kontrollerde Salkım güvesi zararı, yumurtas1, larvası ve pupas1 aranmıştır. Söz konusu unsurların bulunduğu üzüm salkımları bulaşık olarak kabul edilip kaydedilmiş ve bulaşıklı oranları tespit edilmiștir. Gözlemler sırasında bulunan L. botrana'nın açılmamış yumurtaları bir keçeli kalem yardımıyla işaretlenerek hem larva çıkışı kontrol edilmiş hem de sonraki incelemelerde tekrar bulaşıklığa dahil edilmesi önlenmiștir. Deneme bağlarında bulaşıklık oranlarını belirlemek amacıyla yapılan kontroller bağların hasat
23 Ağustos ve 22 Ağustos tarihine kadar her hafta düzenli olarak sürdürülmüştür.

\section{Bulgular}

\subsection{Salkım Güvesi’nin Popülasyon Değişimi}

Lobesia botrana'nın Ahmetli ve Turgutlu ilçelerinde belirlenen bağ alanlarında popülasyon değişimini belirlemek amaciyla 2012-2013 yıllarında çalışmalar yürütülmüștür.

Her iki ilçede deneme bağlarına 26.03.2012 tarihinde asılan eşeysel çekici feromon tuzaklarının ilk kontrolleri 29.03.2012 tarihinde yapılmış ve tüm tuzaklarda ergin bireylerin olduğu görülmüştür. Ahmetli ve Turgutlu ilçelerindeki deneme bağlarına 11.03.2013 tarihinde asılan eşeysel çekici feromon tuzaklarının ilk kontrolleri ise 14.03.2013 tarihinde yapılmış olup, Ataköy dışındaki tüm tuzaklarda ergin bireylerin olduğu gözlemlenmiştir. Eşeysel çekici feromon tuzakları 2012 ve 2013 yillarında sirasıyla 11 Ekim ve 10 Ekim tarihlerinde deneme bağlarından kaldırılmıştır.

\subsection{Zararlının Ahmetli ilçesinde 2012 ve 2013 yıllarındaki popülasyon değişimi}

Salkım güvesinin Ahmetli ilçesine bağlı Ataköy'deki bağda 2012 ve 2013 yıllarındaki ergin popülasyon gelişimi Şekil 1'de verilmiştir. Ataköy'deki bağda Salkım güvesi ilk erginleri 2012 ve 2013 yıllarında mart ayının sonlarında tuzaklarda yakalanmıştır. Ataköy'de 2012 yılında en fazla ergin 23 Ağustos'ta 276 adet/tuzak ile hasat döneminden sonra da 453 adet/tuzak olmuştur. 2013 y1lında en fazla ergin hasat dönemine kadar 306 adet/tuzak ile 22 Ağustos, hasat döneminden sonra ise 426 adet/tuzak ile 12 Eylül tarihlerinde yakalanmıştır. L. botrana'nın her iki yıl için hasat dönemine kadar üç hasattan sonra da bir olmak üzere toplam dört tepe noktası oluşturduğu görülmüştür. Tepe noktalarının 2012 yılında 12 Nisan, 14 Haziran, 26 Temmuz ile 6 Eylül tarihlerinde, 2013 yılında 11 Nisan, 30 Mayıs, 11 Temmuz ile 12 Eylül tarihlerinde oluştuğu tespit edilmiştir (Şekil 1).

Salkım güvesinin Ahmetli ilçesine bağlı Gökkaya beldesindeki bağda 2012 ve 2013 yıllarındaki ergin popülasyon gelişimi Şekil 2'de verilmiştir. 


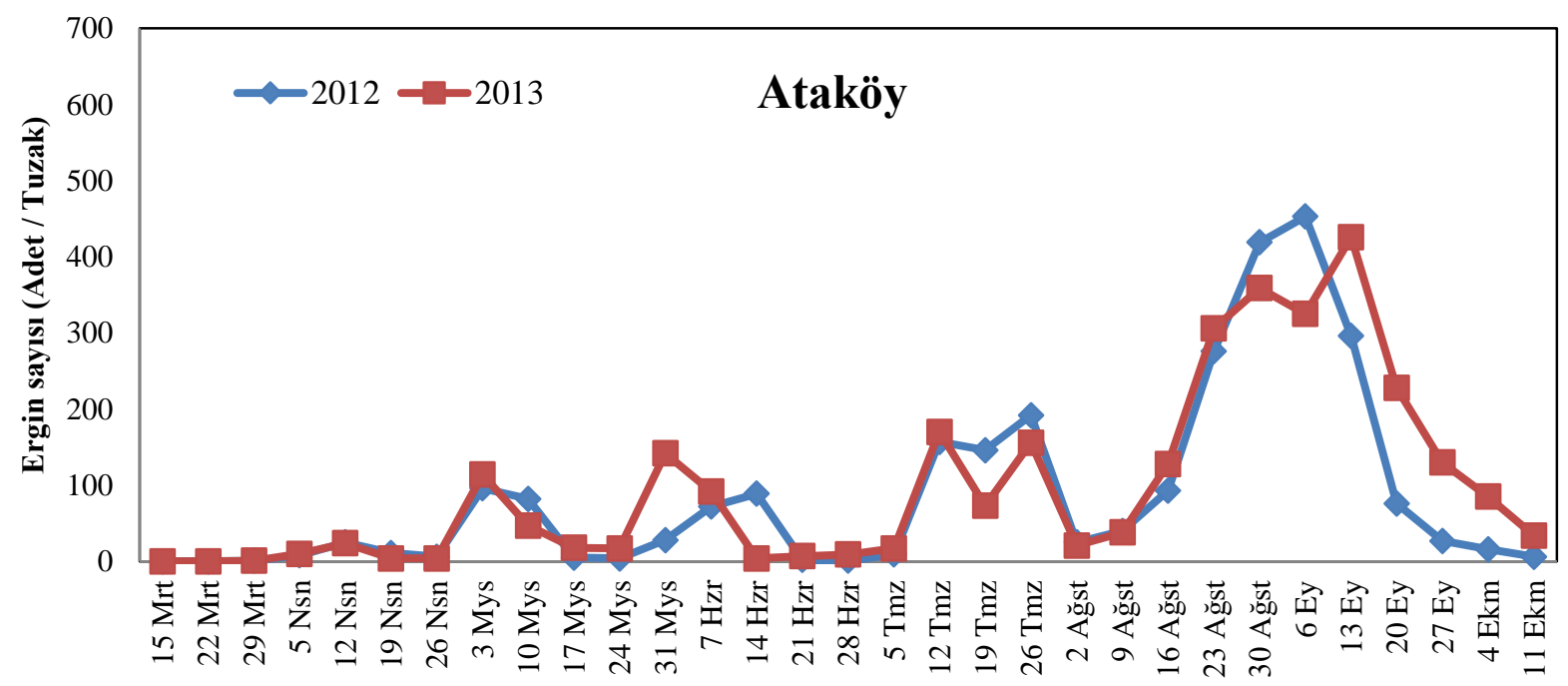

Şekil 1. Lobesia botrana'nın Ataköy'de 2012 ve 2013 yıllarında ergin popülasyon değişimi

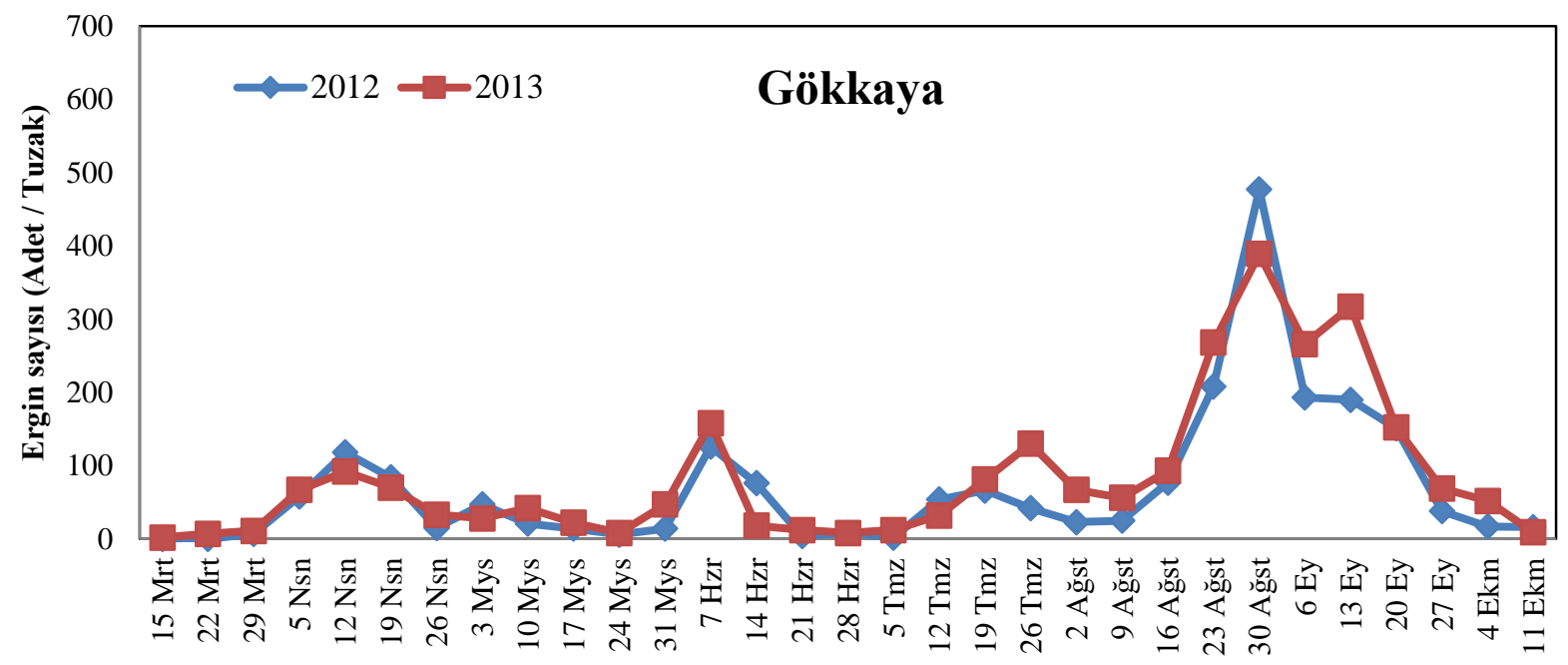

Şekil 2. Lobesia botrana'nın Gökkaya'da 2012 ve 2013 yıllarında ergin popülasyon değişimi

Şekil 2 incelendiğinde, Gökkaya beldesindeki bağda Salkım güvesi ilk erginleri 2012 ve 2013 yıllarında sirasıyla 29 Mart ve 14 Mart tarihlerinde eşeysel çekici tuzaklarda yakalanmıştır. Gökkaya beldesinde 2012 yilında en fazla ergin hasat dönemine kadar 208 adet/tuzak ile 23 Ağustos, hasat döneminden sonra ise 477 adet/tuzak ile 30 Ağustos'ta gerçekleşmiştir. 2013 y1lında en fazla ergin hasat dönemine kadar 268 adet/tuzak ile 22 Ağustos, hasat döneminden sonra ise 389 adet/tuzak ile 29 Ağustos tarihlerinde yakalanmıştır. L. botrana'nın her iki yıl için hasat dönemine kadar üç hasattan sonra da bir olmak üzere toplam dört tepe noktası oluşturduğu görülmüştür. Tepe noktalarının 2012 yılında 12 Nisan, 7 Haziran, 19 Temmuz ile 30 Ağustos tarihlerinde, 2013 yilında 11 Nisan, 6 Haziran, 25 Temmuz ile 29 Ağustos tarihlerinde oluştuğu tespit edilmiştir.

Salkım güvesinin Ahmetli ilçesine bağl Karaköy'deki bağda 2012 ve 2013 yıllarındaki ergin popülasyon gelişimi Şekil 3'te verilmiştir.

Şekil 3'te görüldüğü gibi, Karaköy'deki bağda Salkım güvesi ilk erginleri 2012 ve 2013 yıllarında sırasıyla 29 Mart ve 14 Mart tarihlerinde eşeysel çekici tuzaklarda yakalanmıștır. Karaköy'de 2012 yılında en fazla ergin hasat dönemine kadar 394 adet/tuzak ile 23 Ağustos, hasat döneminden sonra ise 457 adet/tuzak ile 30 Ağustos, 2013 yılında en fazla ergin hasat dönemine kadar 148 adet/tuzak ile 22 Ağustos, hasat döneminden sonra ise 298 adet/tuzak ile 5 Eylül tarihlerinde yakalanmıştır. Ergin popülasyon gelişim grafiklerinde, L. botrana'nın her iki yıl için hasat dönemine kadar üç hasattan sonra da bir olmak üzere toplam dört tepe noktası oluşturduğu görülmüștür. Tepe noktalarının 2012 yılında 12 Nisan, 14 Haziran, 19 Temmuz ile 30 Ağustos tarihlerinde, 2013 yılında 11 Nisan, 6 Haziran, 25 Temmuz ile 5 Eylül tarihlerinde oluştuğu tespit edilmiştir. 


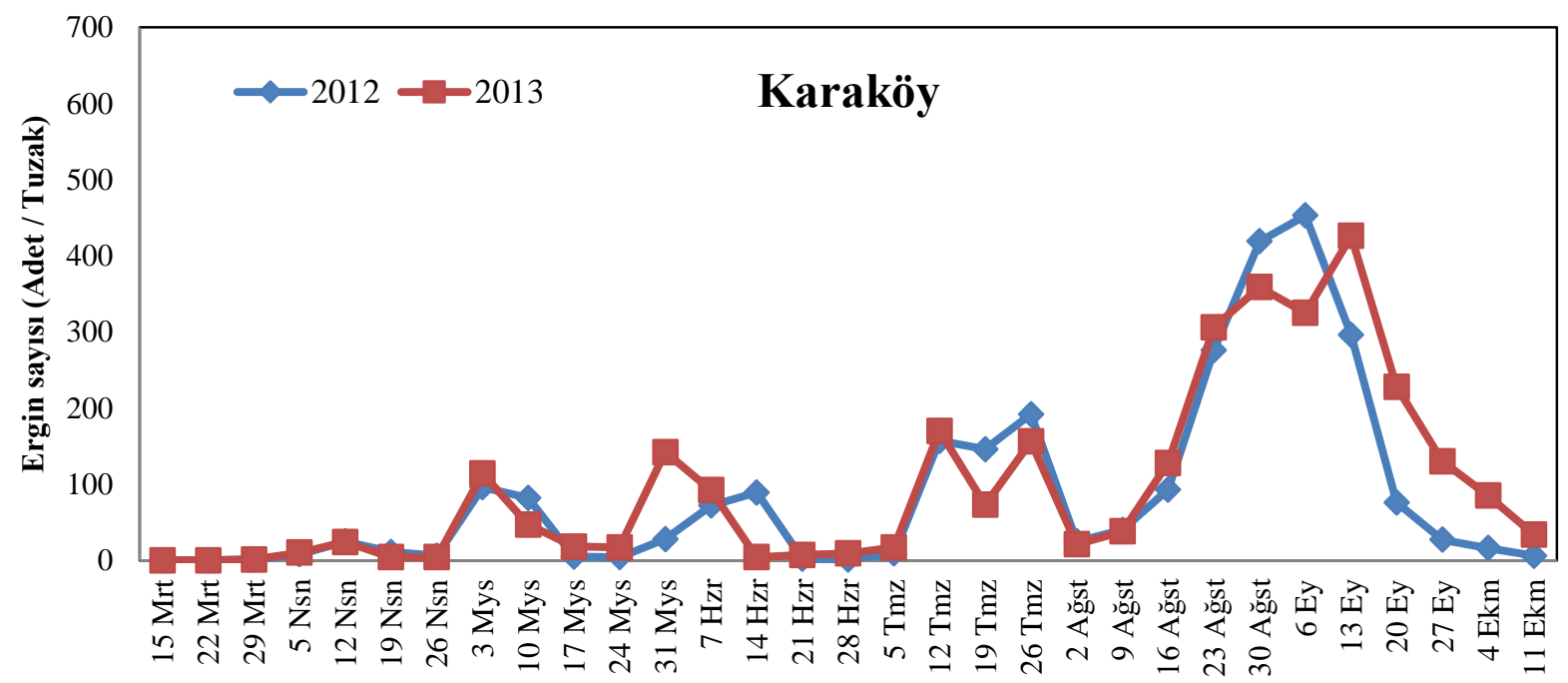

Şekil 3. Lobesia botrana'nın Karaköy’de 2012 ve 2013 yıllarında ergin popülasyon değişimi

Salkım güvesinin Ahmetli ilçesine bağlı Kestelli köyündeki bağda 2012 ve 2013 yıllarındaki ergin popülasyon gelişimi Şekil 4'te verilmiştir. Şekil 4 incelendiğinde, Kestelli köyündeki bağda Salkım güvesi ilk erginleri 2012 ve 2013 yıllarında sirasiyla 29 Mart ve 14 Mart tarihlerinde eşeysel çekici tuzaklarda yakalanmıştır. Kestelli köyünde 2012 yılında en fazla ergin hasat dönemine kadar 292 adet/tuzak ile 23 Ağustos, hasat döneminden sonra ise 346 adet/tuzak ile 30 Ağustos, 2013 yılında en fazla ergin hasat dönemine kadar 238 adet/tuzak ile 22 Ağustos, hasat döneminden sonra ise 295 adet/tuzak ile 12 Eylül tarihlerinde yakalanmıştır. Ergin popülasyon gelişim grafiklerinde, L. botrana'nın her iki yıl için hasat dönemine kadar üç hasattan sonra da bir olmak üzere toplam dört tepe noktası oluşturduğu görülmüştür. Tepe noktalarının 2012 yilında 12 Nisan, 14 Haziran, 19 Temmuz ile 30 Ağustos tarihlerinde, 2013 y1lında 11 Nisan, 30 Mayıs, 11 Temmuz ile 12 Eylül tarihlerinde oluştuğu tespit edilmiştir.

\subsection{Zararlının Turgutlu ilçesinde 2012 ve 2013 yıllarındaki popülasyon değişimi}

Salkım güvesinin Turgutlu ilçesine bağlı Akçapınar köyündeki bağda 2012 ve 2013 yıllarındaki ergin popülasyon gelişimi Şekil 5'te verilmiştir. Şekil 5 incelendiğinde, Akçapınar köyündeki bağda L. botrana ilk erginleri 2012 ve 2013 yıllarında sirasıly 29 Mart ve 14 Mart tarihlerinde eşeysel çekici tuzaklarda yakalanmıştır. Akçapınar köyünde 2012 yılında en fazla ergin hasat dönemine kadar 311 adet/tuzak ile 23 Ağustos, hasat döneminden sonra ise 504 adet/tuzak ile 30 Ağustos, 2013 yılında en fazla ergin hasat dönemine kadar 343 adet/tuzak ile 22 Ağustos, hasat döneminden sonra ise 432 adet/tuzak ile 29 Ağustos tarihlerinde yakalanmıştır.

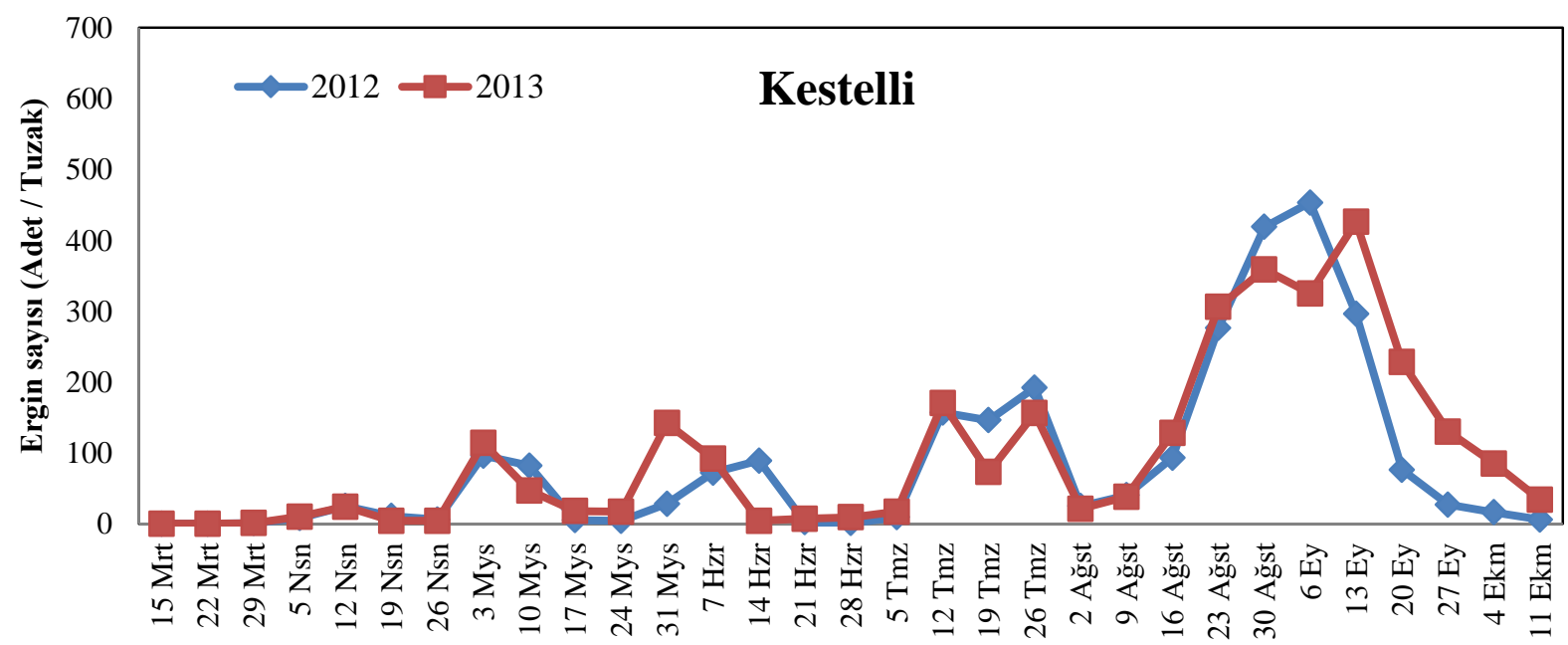

Şekil 4. Lobesia botrana'nın Kestelli'de 2012 ve 2013 yıllarında ergin popülasyon değişimi 


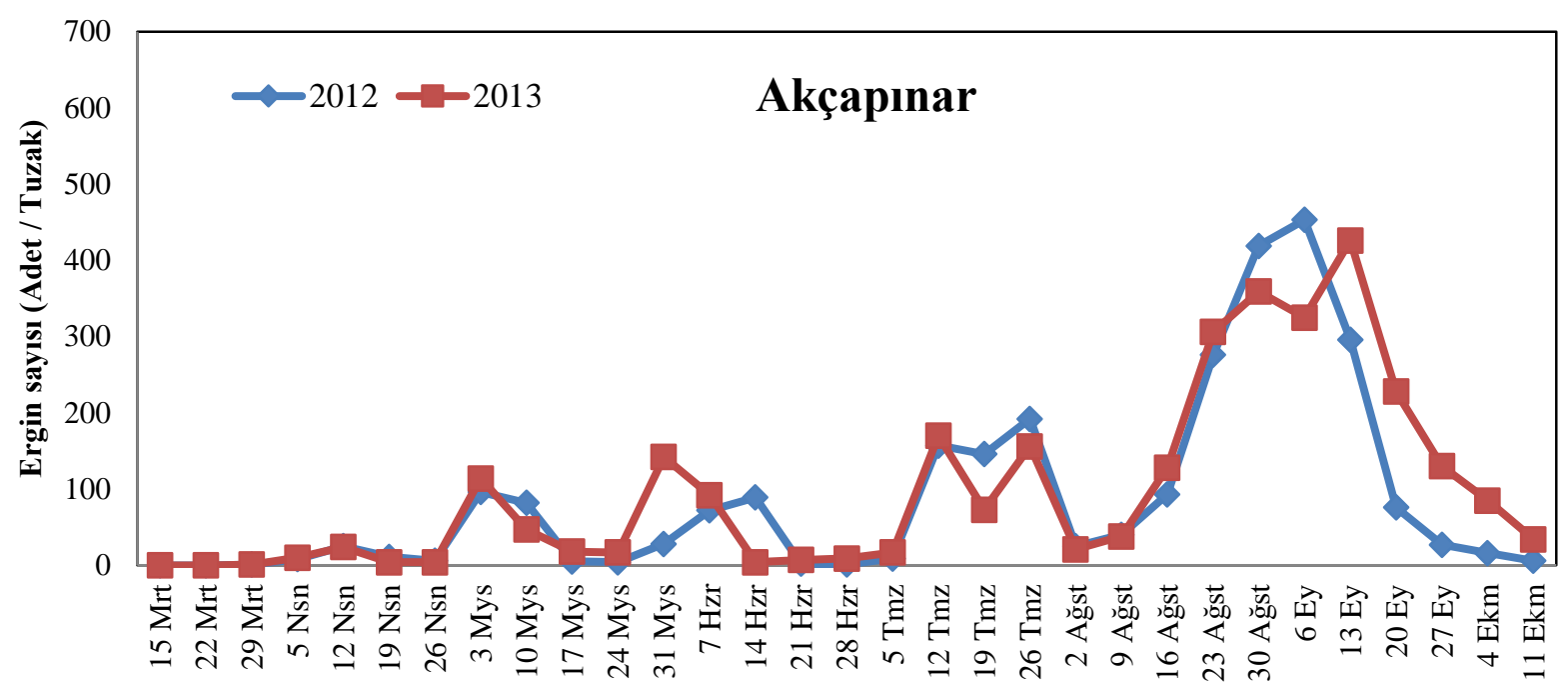

Şekil 5. Lobesia botrana'nın Akçapınar'da 2012 ve 2013 yıllarında ergin popülasyon değişimi

Ergin popülasyon gelişim grafiklerinde, $L$. botrana'nın her iki yıl için hasat dönemine kadar üç hasattan sonra da bir olmak üzere toplam dört tepe noktası oluşturduğu görülmüştür. Tepe noktalarının 2012 y1lında 19 Nisan, 14 Haziran, 26 Temmuz ile 30 Ağustos tarihlerinde, 2013 yllında 11 Nisan, 6 Haziran, 11 Temmuz ile 29 Ağustos tarihlerinde oluştuğu tespit edilmiştir. Lobesia botrana'nın popülasyon yoğunluğu bakımından 2013 yılında 11 Temmuz ve 25 Temmuz tarihleri arasında dalgalanma oluşturduğu gözlemlenmiştir. Bu duruma sıcaklık, nem, rüzgar gibi iklim faktörlerinin yanı sıra zamansız yapılan ilaçlamaların da neden olabileceği düşünülmektedir.

Salkım güvesinin Turgutlu ilçesine bağlı Derbent beldesindeki bağda 2012 ve 2013 yıllarındaki ergin popülasyon gelişimi Şekil 6'da verilmiştir. Şekil 6'da görüldüğü gibi, Derbent beldesindeki bağda $L$. botrana ilk erginleri 2012 ve 2013 yıllarında sirasıyla 29 Mart ve 14 Mart tarihlerinde eşeysel çekici tuzaklarda yakalanmıştır. Derbent beldesinde 2012 yılında en fazla ergin hasat dönemine kadar 439 adet/tuzak ile 23 A ğustos, hasat döneminden sonra ise 454 adet/tuzak ile 30 Ağustos, 2013 yılında en fazla ergin hasat dönemine kadar 208 adet/tuzak ile 11 Nisan, hasat döneminden sonra ise 598 adet/tuzak ile 12 Eylül tarihlerinde yakalanmışıtır. Ergin popülasyon gelişim grafiklerinde, L. botrana'nın her iki yıl için hasat dönemine kadar üç hasattan sonra da bir olmak üzere toplam dört tepe noktası oluşturduğu görülmüştür.

Tepe noktalarının 2012 yılında 26 Nisan, 14 Haziran, 26 Temmuz ile 30 Ağustos tarihlerinde, 2013 yılında 11 Nisan, 6 Haziran, 25 Temmuz ile 12 Eylül tarihlerinde oluştuğu tespit edilmiștir. Salkım güvesinin Turgutlu ilçesine bağlı Musacalı köyündeki bağda 2012 ve 2013 yıllarındaki ergin popülasyon gelişimi Şekil 7'de verilmiştir.

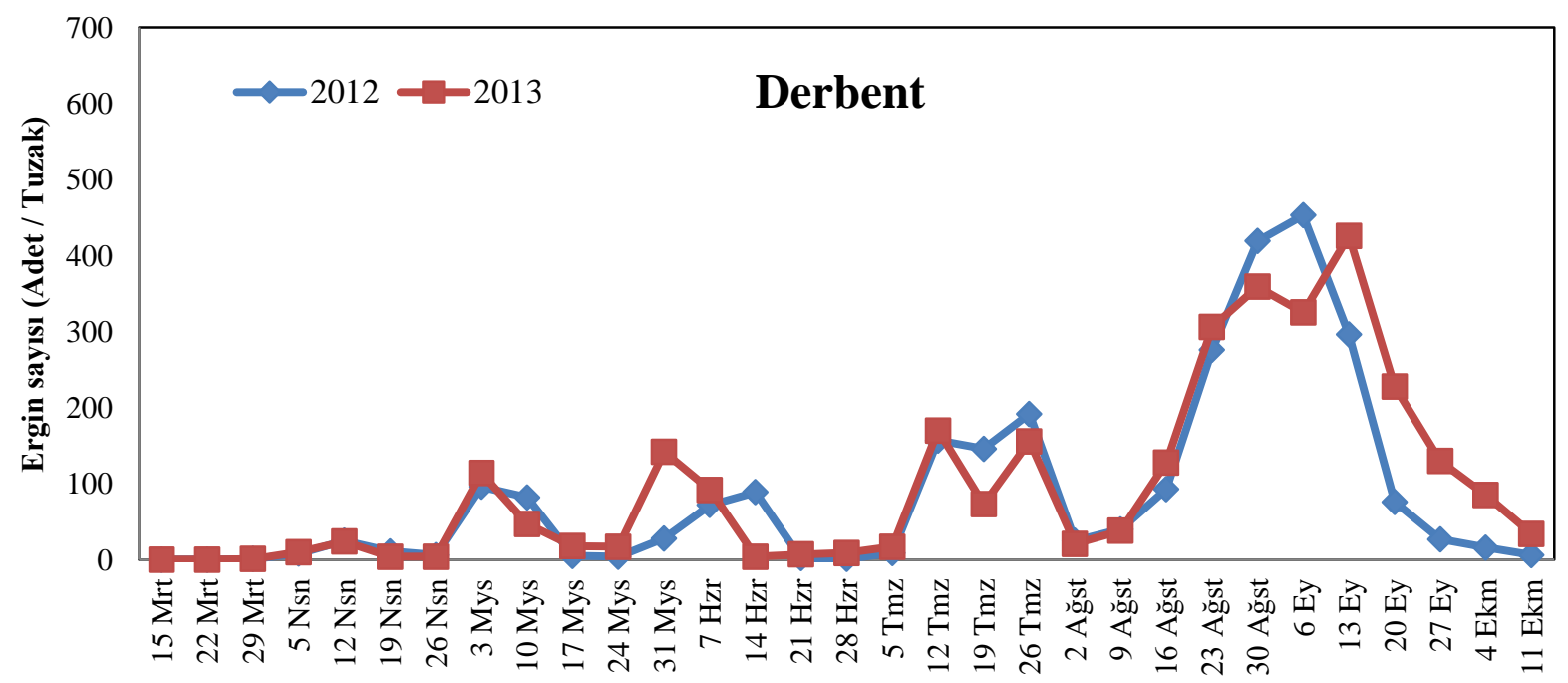

Şekil 6. Lobesia botrana'nın Derbent'te 2012 ve 2013 yıllarında ergin popülasyon değişimi 


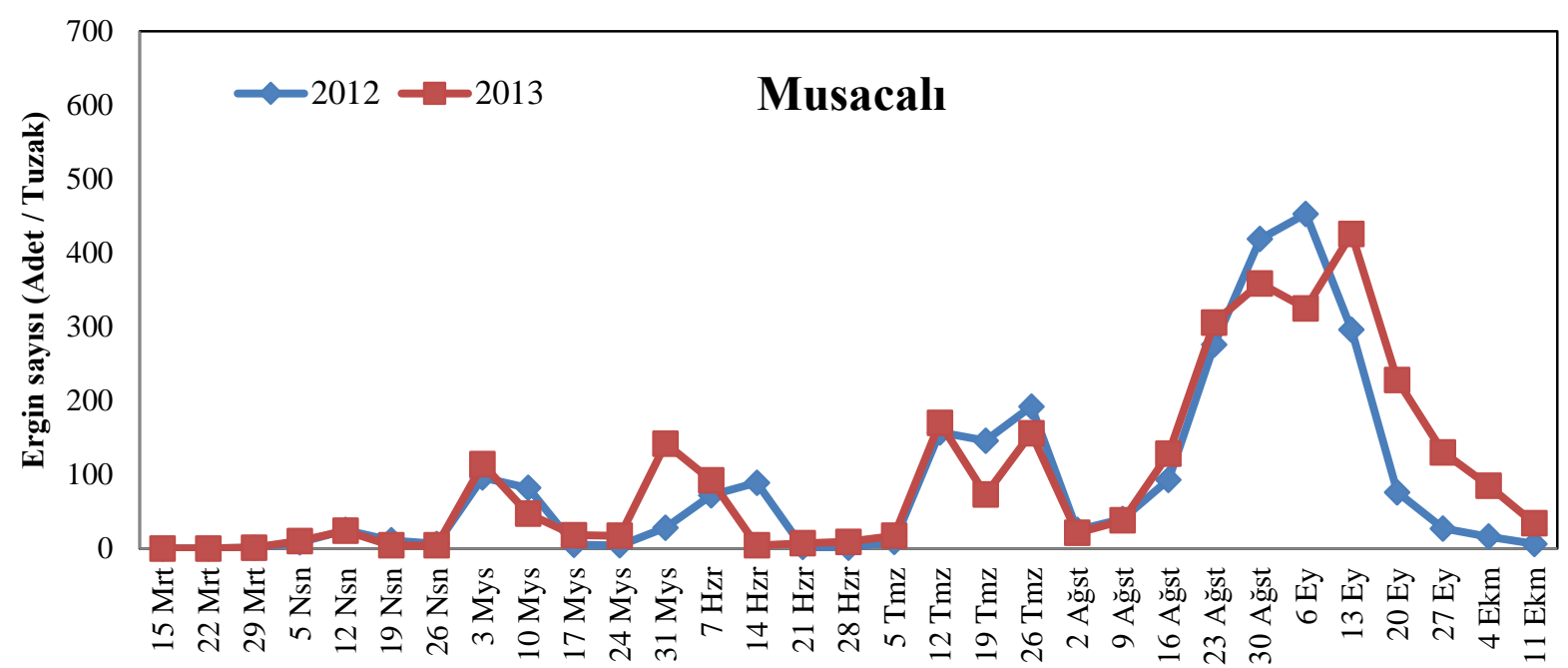

Şekil 7. Lobesia botrana'nın Musacalı'da 2012 ve 2013 yıllarında ergin popülasyon değişimi

Şekil 3’te görüldüğü gibi, Karaköy'deki bağda Salkım güvesi ilk erginleri 2012 ve 2013 yıllarında sırasıyla 29 Mart ve 14 Mart tarihlerinde eşeysel çekici tuzaklarda yakalanmıştır. Karaköy'de 2012 yılında en fazla ergin hasat dönemine kadar 394 adet/tuzak ile 23 Ağustos, hasat döneminden sonra ise 457 adet/tuzak ile 30 Ağustos, 2013 yılında en fazla ergin hasat dönemine kadar 148 adet/tuzak ile 22 Ağustos, hasat döneminden sonra ise 298 adet/tuzak ile 5 Eylül tarihlerinde yakalanmıştır. Ergin popülasyon gelişim grafiklerinde, L. botrana'nın her iki yıl için hasat dönemine kadar üç hasattan sonra da bir olmak üzere toplam dört tepe noktas1 oluşturduğu görülmüştür. Tepe noktalarının 2012 yllında 12 Nisan, 14 Haziran, 19 Temmuz ile 30 Ağustos tarihlerinde, 2013 yilında 11 Nisan, 6 Haziran, 25 Temmuz ile 5 Eylül tarihlerinde oluştuğu tespit edilmiştir.

Şekil 7 incelendiğinde, Musacalı köyündeki bağda L. botrana ilk erginleri 2012 ve 2013 yıllarında sirasiyla 29 Mart ve 14 Mart tarihlerinde eşeysel çekici tuzaklarda yakalanmıştır. Musacalı köyünde 2012 yılında en fazla ergin hasat dönemine kadar 420 adet/tuzak ile 23 Ağustos, hasat döneminden sonra ise 352 adet/tuzak ile 30 Ağustos, 2013 y1lında en fazla ergin hasat dönemine kadar 178 adet/tuzak ile 4 Nisan, hasat döneminden sonra ise 197 adet/tuzak ile 5 Eylül tarihlerinde yakalanmıştır. Ergin popülasyon gelişim grafiklerinde, L. botrana'nın her iki yıl için hasat dönemine kadar üç hasattan sonra da bir olmak üzere toplam dört tepe noktası oluşturduğu görülmüştür. Tepe noktalarının 2012 yılında 19 Nisan, 7 Haziran, 26 Temmuz ile 23 Ağustos tarihlerinde, 2013 yılında 4 Nisan, 6 Haziran, 25 Temmuz ile 5 Eylül tarihlerinde oluş̧uğu tespit edilmiştir.

Salkım güvesinin Turgutlu ilçesi Sarıbey'de 2012 ve 2013 yıllarındaki ergin popülasyon gelişimi Şekil 8'de verilmiştir.

Şekil 8'de görüldüğü gibi, Sarıbey köyündeki bağda L. botrana ilk erginleri 2012 ve 2013 yıllarında sırasiyla
29 Mart ve 14 Mart tarihlerinde eşeysel çekici tuzaklarda yakalanmıştır.

Sarıbey köyünde 2012 yılında en fazla ergin hasat dönemine kadar 353 adet/tuzak ile 23 Ağustos, hasat döneminden sonra ise 471 adet/tuzak ile 30 Ağustos, 2013 yılında en fazla ergin hasat dönemine kadar 345 adet/tuzak ile 22 Ağustos, hasat döneminden sonra ise 647 adet/tuzak ile 12 Eylül tarihlerinde yakalanmıştır. Ergin popülasyon gelişim grafiklerinde, L. botrana'nın her iki yıl için hasat dönemine kadar üç hasattan sonra da bir olmak üzere toplam dört tepe noktası oluşturduğu görülmüştür. Tepe noktalarının 2012 yılında 26 Nisan, 14 Haziran, 26 Temmuz ile 30 Ağustos tarihlerinde, 2013 yllında 11 Nisan, 6 Haziran, 25 Temmuz ile 12 Eylül tarihlerinde oluştuğu tespit edilmiştir.

Manisa ilinde kurutmalık üzüm üretimi ve sahip olduğu bağ alanları bakımından önemli bir paya sahip olan Ahmetli ve Turgutlu ilçelerinde, 2012 ve 2013 yıllarında Salkım güvesi popülasyon değişim grafikleri birlikte değerlendirildiğinde ergin bireylerin ilk olarak her iki ilçede de Mart başı ve sonu arasında (14-29 Mart) çıkış yaptığı görülmüştür. Önçağ (1975), L. botrana'nın İzmir, Denizli ve Manisa illerinde, ergin çıkışının Nisan ayının ikinci yarısında başladığını tespit etmiştir. Özbek ve ark. (1995), Salkım güvesi ilk erginlerinin ülkemizin değişik bölgelerinde farklı zamanlarda çıkış yaptı̆̆ını bildirmektedirler. Kaplan ve Çınar (1998), Güneydoğu Anadolu Bölgesi'nde Salkım güvesi ilk erginlerinin Nisan ayı sonlarında çıkış yaptığını, Özpınar ve ark. (2004) ise Çanakkale bağlarında Salkım güvesi ilk erginlerinin Nisan sonuMayıs ayı ilk yarısında görüldüğünü kaydetmişlerdir. İznik ve Bursa'da Salkım güvesi ilk erginlerinin Nisan ayı ikinci yarısında çıkış yaptığı bildirilmiştir (Kovancı ve ark., 2005; Altındişli ve ark., 2005). Karadağ ve ark. (2011), Gaziantep yöresinde Salkım güvesi ergin çıkışlarının Nisan ayı ortalarında başladığını tespit etmişlerdir. İlk ergin çıkışları sıcaklığa bağlı olarak değişiklik gösterebilmektedir. 


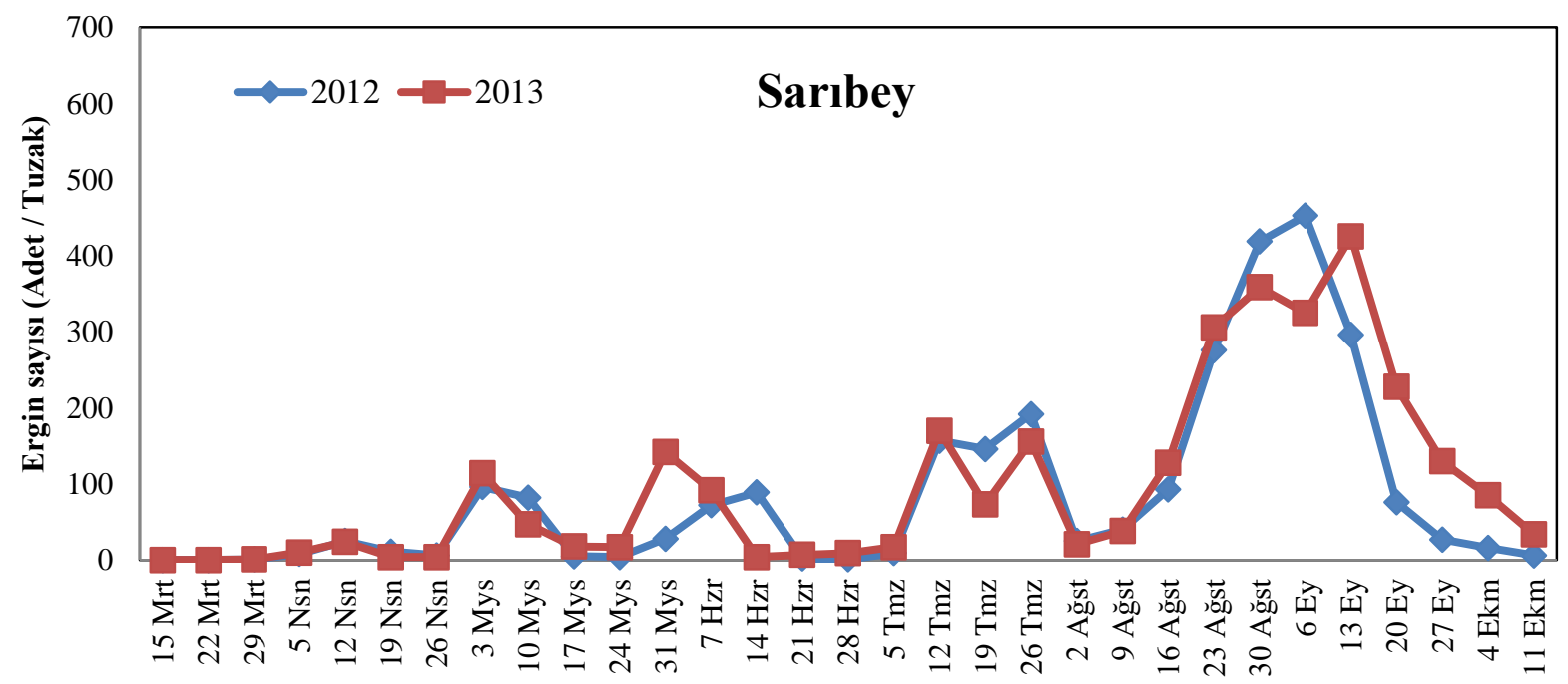

Şekil 8. Lobesia botrana'nın Sarıbey'de 2012 ve 2013 yıllarında ergin popülasyon değişimi

Zararlının sadece ergin popülasyon gelişimine bakarak döl sayısına karar vermek eksik kalabilir. Aynı zamanda yumurta ve larva sayılarını da incelemek gerekmektedir. Fakat feromon tuzaklarındaki ergin sayısı da döl sayısına karar vermede etkili olmaktadır. Lobesia botrana'nın Ahmetli ve Turgutlu ilçelerinde yılda dört defa tepe noktası oluşturduğu görülmüştür. Zararlının Ege, Marmara ve Güneydoğu Anadolu bölgelerinde genellikle üç döl verdiği (Önçağ, 1975; Altay ve ark., 1978; Kaplan ve Çınar, 1998). Çanakkale bağlarında $L$. botrana'nın üç döl vermesine rağmen bazı yıllar hasattan sonra dördüncü bir tepe noktası oluştuğu (Özpınar ve ark., 2004), Bursa'da ise zararlının dört döl verdiği bildirilmektedir (Kovanc1 ve ark., 2005; Altındişli ve ark., 2005). Özbek ve ark. (1995), $L$. botrana'nın ülkemizin değiş̧ik bölgelerinde farklı sayıda döl verdiğini, Türkiye'de genellikle üç döl verdiğini, ancak iklim koşullarına göre bazı bölgelerde dört döl verdiğini kaydetmişlerdir. Sipahi (1956), Gaziantep'te L. botrana'nın yılda 3-4 döl verdiğini, Ataç ve ark. (1987), Ankara bağlarında L. botrana'nın iki döl verdiğini, Öztürk ve Acıöz (2010), Tarsus (Mersin) yöresi bağlarında $L$. botrana'nın yılda dört döl verdiğini tespit etmişlerdir. Öztürk ve Şahin (2013), Gaziantep ili İslahiye ilçesi bağ alanlarında $L$. botrana'nın yılda dört kez tepe noktası oluşturduğunu bildirmişlerdir.

Saeidi ve Kavoosi (2011), Sisakht (İran) bölgesinde L. botrana'nın üç neslinin olduğunu ve tamamlanmamış dördüncü neslinin bulunduğunu bildirmişlerdir.

Salkım güvesi, hasat dönemine kadar en fazla haftalık popülasyon yoğunluğunu, 2012 yılında Ahmetli ilçesinde Karaköy (394 ergin/tuzak), Turgutlu ilçesinde Derbent (439 ergin/tuzak) köy ve beldelerinde bulanan bağ alanlarında 23 Ağustos tarihinde, 2013 yılında ise Ahmetli ilçesinde Ataköy (306 ergin/tuzak), Turgutlu ilçesinde Sarıbey (345 ergin/tuzak) ve Akçapınar (343 ergin/tuzak) köylerinde bulunan bağlarda 22 Ağustos tarihinde oluşturmuştur. Hasattan sonra ise en fazla haftalık popülasyon yoğunluğunu, 2012 yılında Ahmetli ilçesinde Gökkaya (477 ergin/tuzak) beldesinde, Turgutlu ilçesinde Akçapınar (504 ergin/tuzak) köyünde 30 Ağustos tarihinde, 2013 yllında ise Ahmetli ilçesinde Ataköy (426 ergin/tuzak) ve Turgutlu ilçesinde Sarıbey (647 ergin/tuzak) köylerinde bulunan deneme bağlarında 12 Eylül tarihinde oluşturduğu gözlemlenmiştir.

\subsection{Salkım Güvesi'nin Bulaşıklık Oranı}

Ahmetli ve Turgutlu ilçelerinde belirlenen bağlarda, L. botrana'nın bulaşıklık oranını saptamak üzere 20122013 yıllarında söz konusu alanlarda çalışmalar yürütülmüştür.

Lobesia botrana'nın bağ alanlarındaki bulaşıklık oranını belirlemek için kontrollere asma fenolojisinin salkım somaklarında somak çilkimlerinin birbirinden ayrılma safhasına girmeye yakın olduğu dönemde (26.04.2012) başlanmıştır. Kontroller bağların hasat edilmeye başlandığ 23.08 .2012 tarihine kadar her hafta düzenli olarak sürdürülmüş, sonuçlar ortalama olarak verilmiştir.

Lobesia botrana'ya ait 2012-2013 yıllarında çalışma alanlarında tespit edilen bulaşıklık oranları Çizelge 2'de verilmiştir.

Lobesia botrana'nın meydana getirdiği ortalama bulaşıklık oranları 2012 yılında Ahmetli ilçesi Ataköy, Gökkaya, Karaköy ve Kestelli'de sirasiyla \%9.77, $15.61,10.61$ ve 4.22 olarak, Turgutlu ilçesi Akçapınar, Derbent, Musacalı ve Sarıbey'de yine sirasiyla \% 6.55, 9.05, 4.88 ve 13.94 olarak belirlenmiştir. En fazla bulaşıklık 23.08.2012 tarihinde Ahmetli ilçesinde Gökkaya beldesi ve Karaköy'de bulunan bağlarda \% 46, Turgutlu ilçesinde Sarıbey köyünde bulunan bağda \% 41 olarak tespit edilmiştir.

Lobesia botrana'nın meydana getirdiği ortalama bulaşıklık oranları 2013 y1lında Ahmetli ilçesi Ataköy, Gökkaya, Karaköy ve Kestelli'de sirasıyla \% 9.16, 18.21, 13.79 ve 3.58 olarak, Turgutlu ilçesi Akçapınar, Derbent, Musacalı ve Sarıbey'de yine sirasiyla \% 3.42, 
5.42, 1.16 ve 19.79 olarak belirlenmiştir. En fazla bulaşıklık 22.08.2013 tarihinde Ahmetli ilçesinde Gökkaya beldesinde bulunan bağda \% 58, Turgutlu ilçesinde Sarıbey köyünde bulunan bağda \% 62 olarak tespit edilmiştir. Çalışmanın iki yılı birlikte değerlendirildiğinde $L$. botrana'nın en fazla bulaşıklık oranına, 2013 yılında Ahmetli ve Turgutlu ilçelerinde sırasıyla Gökkaya beldesi (\% 58) ve Sarıbey köyünde (\% 62) ulaştığ 1 görülmüştür. 2012 ve 2013 yıllarında bulaşma oranının en yüksek olduğu tarihlerde bağların olgunlaşma-hasat döneminde olduğu belirlenmiştir. Nitekim, Kısakürek (1972), en fazla bulaşıklığın olgun üzüm devresinde görüldüğünü, Sipahi (1956) ise üçüncü döl zararının diğer döllere göre daha ağır olduğunu belirtmiştir. Altay (1981), belirgin olarak en çok zararı üçüncü dölün larvalarının yaptığını bildirmiştir. Salkım güvesi nesillerinin zararı ve asmanın fenolojisi ilişkilendirildiğinde; 1 . döl zararının tomurcuk ve çiçek döneminde, 2. döl zararının koruk döneminde, 3. döl zararının olgunlaşma döneminde ve hasattan sonra meydana gelen 4. döl zararının neferne döneminde oluştuğu gözlemlenmiştir. İyriboz (1938), Salkım güvesi larvalarının çiçek devresinde salkımları ince ağlarla bağlayıp onları kemirip kuruttuğunu, koruk devresinde daneleri kemirmek, delmek, ağlarla birbirine bağlamak ve bir daneden diğerine geçmek suretiyle zarar yaptı̆̆ını, olgun üzüm devresinde daneleri yiyerek şekerli sıvıların akmasına ve bu sıvıların üzerinde saprofit mantarların çoğalmasına ve sonunda salkımların çürümesine sebep olduğunu belirtmiştir. Sipahi (1956), Salkım güvesi birinci döl larvalarının tomurcuk halindeki salkımları ağlarla sararak onları mahvettiklerini, ikinci döl larvalarının takriben bezelye büyüklüğündeki koruklarda zarar yaptıklarını, üçüncü döl larvalarının olgun daneleri yaralayıp mantari enfeksiyonların yayılmasına ve üzüm suyunun akmasına sebep olduklarını bildirmişlerdir.

Çalışmanın yürütüldüğü 2012 ve 2013 yılları birlikte değerlendirildiğinde saptanan ortalama bulaşıklık oranlarının Ahmetli ve Turgutlu ilçelerinde sırasıyla \% 3.58-18.21 ve \% 1.16-19.79 arasında olduğu tespit edilmiştir. Önçağ (1975), L. botrana'nın Ege Bölgesi’nde yaygın şekilde görüldügünü ve büyük zarara neden olduğunu kaydetmiştir. Maçan (1984), bağlarda tomurcuk, çiçek ve meyve ile beslenen $L$. botrana'nın salgın yaptığı yıllarda \% 90-93 oranında zarara neden olduğunu belirtmiş̧ir. Altay (1981), L. botrana'nın Marmara Bölgesi'nde y1llara göre zarar derecesinin \% 5-75 oranında değiştiğini, Karabulut ve
Demirel (2014) ise Manisa ilinin Turgutlu ilçesi bağlarında $L$. botrana'nın \% 5-7 arasında zarar oranı meydana getirdiğini bildirmiş̧lerdir. Mamay ve Çakır (2014), Şanlıurfa'da Salkım güvesi bulaşıklık oranını en fazla 2011-2012 yıllarında sirasıyla \% 52 ila $\% 34$ olarak tespit etmişlerdir.

Lobesia botrana'nın ikinci ve üçüncü döl larvalarının beslenmesi bir tane içerisinde olmayıp birden çok tanede beslenmektedir. Nitekim, Saeidi ve Kavoosi (2011), tanelerin büyük ölçüde ikinci ve üçüncü nesil larvalar tarafından zarar gördüğünü bildirmişlerdir. Özellikle üçüncü döl larvalarının olgun tanelerde beslenmesi sonucu meydana gelen yaralardan tatlı su akmakta ve çürümeler meydana gelmektedir. $\mathrm{Bu}$ durum Okratoksin-A (OTA) oluşumuna neden olmaktadır. OTA, Penicillium ve Aspergillus cinsi küfler tarafindan üretilmektedir (Ringot ve ark, 2006). Eltem ve ark. (2003), Ege Bölgesi koşullarının kuru üzümde OTA oluşumu açısından uygun olduğunu ve özellikle OTA oluşumunun hasat öncesinde tarlada başladığını belirtmişlerdir.

Üzümler hasat edilirken ekonomik önemi olmayan salkımların omca üzerinde bırakılması, zararlının bir sonraki yıla daha yüksek bir popülasyon ile geçmesine sebebiyet vereceğinden, hasat sirasında bu salkımlar koparılıp atılmalıdır (Şekerden Çağlar, 2009).

\section{Sonuç}

Yapılan çalışmayla Salkım güvesinin Manisa ilinde halen ve yoğun olarak zararına devam ettiği belirlenmiştir. Üreticilerimiz yıllardır sadece kimyasal mücadele uygularlarken, son yıllarda biyolojik ve biyoteknik mücadelelerinde faydasını görüp kullanmaya başlamışlardır.

Salkım güvesi erginlerinin popülasyon gelişiminde kullanılan feromon tuzakları hem ergin sayısını azaltırken hem de kimyasal mücadele uygulamalarının zamanını da belirlemektedir. Amaç hedefe ulamak için en uygun zamanda kimyasalların uygulanmasidır. Bunu gerçekleştirmek için yumurta ve larva takibinin yanı sıra en güzel yöntem feromon tuzaklarının kullanılmasıdır. Ayrıca üreticilerimizin gözden kaçırdıkları bir nokta da, feromon tuzaklarının asılma zamanıdır. Israrla şunu belirtmek isteriz ki, tuzakların asma tomurcuklarının patlamadan hemen önce kurulması gerekmektedir.

Asmayı askiya almak, budama ve aralamayı asmanın iç kısmını havalandıracak şekilde yapmak, bağı otlu

Çizelge 2. Ahmetli ve Turgutlu ilçeleri bağ alanlarında 2012 yılında Salkım güvesi ile ortalama bulaşıklık oranı (\%)

\begin{tabular}{llccc|cccc}
\hline \multicolumn{3}{c}{ İlçeler } & \multicolumn{5}{c|}{ Ahmetli } & \multicolumn{5}{c}{ Turgutlu } \\
\hline Y1l & Ataköy & Gökkaya & Karaköy & Kestelli & Akçapınar & Derbent & Musacalı & Sarıbey \\
\hline 2012 & 9.77 & 15.61 & 10.61 & 4.22 & 6.55 & 9.05 & 4.88 & 13.94 \\
2013 & 9.16 & 18.21 & 13.79 & 3.58 & 3.42 & 5.42 & 1.16 & 19.79 \\
\hline
\end{tabular}


bırakmamak, kış temizliğine önem vermek, yazın nemi yükseltecek aşırı sulamalardan kaçınmak gibi kültürel uygulamalar da $L$. botrana'nın zararını azaltmak bakımından yararlı olacaktır.

Hem sağlığımız yönünden hem de ihracatta sorunlarla karşılaşmamak amaciyla Okratoksin-A oluşumuna neden olan etkileri ortadan kaldırmak için önlem almak gerekir. $\mathrm{Bu}$ önlemler doğrultusunda bağcıların Salkım güvesi üçüncü dölüne karşı İlçe Müdürlüklerince Tahmin ve Erken Uyarı Sistemine bağlı olarak yapılan yumurta ve larva ilaçlama ilan tarihlerine uymaları faydalı olacaktır.

Gerek doğal düşmanların korunup doğal dengenin bozulmasını önlemek, gerekse üzümde oluşabilecek ilaç kalıntısına bağlı olarak ihracatta sorunlarla karşılaşmamak ve insan sağlığını korumak adına zararlı ile mücadelede biyolojik preparatlara yer verilmelidir.

Birinci neslin genel olarak yüksek popülasyon oluşturmasına rağmen bulaşıklık oranının düşük olması, tomurcuk ve çiçekleri birbirine bağlayıp sadece seyreltme şeklinde zarar yapması, dördüncü neslin ise hasattan sonra ekonomik açıdan önemi olmayan salkımlarda (neferne) zarar oluşturması dolayısıyla bu iki nesle karşı mücadele yapılmaması, ikinci ve özellikle üçüncü nesillerin ise doğrudan tane içinde beslenmesi, bir taneden diğerine geçmek suretiyle büyük tahribata yol açmaları sebebiyle yumurta açılımı veya larva çıkışları takip edilerek ilaçlama yapılması, ayrıca zararlının bir sonraki yılda başlangıç popülasyonunu azaltmak bakımından dördüncü nesle karşı ya da bu uygulamanın yapılamaması durumunda sonraki yılın birinci nesline karşı zararlının gelişme dönemi içindeki popülasyon yoğunluğunu kırmak açısından bir ilaçlamanın yapılması, olgunlaşma döneminde (Temmuz sonu-hasat) zararlının tüm biyolojik dönemlerine rastlamak mümkün olduğu için yumurta durumu, larva çıkışı ve ilacın etki süresi dikkate alınarak zararı azaltmak bakımından üçüncü nesle karşı iki defa ilaçlama yapılması önerilebilir.

\section{Kaynaklar}

Altay, M., Gürses, A., Erkam, B. ve Tüzün, Ş., 1978 Marmara Bölgesi'nde Salkım Güvesi (Lobesia botrana Den. \& Schiff.) (Lepidoptera: Tortricidae)'nin Biyoökolojisi ve Mücadelesi ile Kullanılan İlaçların Bakiye Durumları Üzerinde Araştırmalar, Zirai Mücadele Araştırma Yıllığl, Gıda Tarım ve Hayvancılık Bakanlığı, Zirai Mücadele ve Zirai Karantina Genel Müdürlüğü Araştırma Şubesi, 8: 56-58.

Altay, M., 1981. Salkım Güvesi (Lobesia botrana Den. \& Schiff.) (Lep.: Tortricidae)'ne Karşı Tarımsal Savaşta Erken Uyarı İstasyonlarının Çalışma Düzeni, 1. Bağcılık Simpozyumu Entomoloji Bildirisi, Bölge Zirai Araştırma Enstitüsü, Erenköyİstanbul (Basılmamış).

Altındişli, F.Ö., Kısmalı, Ş., 1996. Ege Bölgesi’nde
Salkım Güvesi (Lobesia botrana Den. \& Schiff.) (Lepidoptera: Tortricidae) ile Mücadelede Kitle Halinde Tuzakla Yakalama Yönteminin Uygulanma Olanakları, Türkiye 3. Entomoloji Kongresi, 24-28 Eylül 1996, Ankara.

Altındişli, F.Ö., Koçlu, T., Hepdurgun, B., Özsemerci, F., 2005. Salkım Güvesi (Lobesia botrana Den. \& Schiff.) ile Mücadelede Çiftleşmeyi Engelleme Tekniğinin Kullanımında 6 Yıllık Deneyim, Türkiye 6. Bă̆cllık Sempozyumu Bildirileri, 19-23 Eylül 2005, Tekirdağ, Cilt: 1, 297-304 s.

Anonim, 1999. Bağ Entegre Mücadele Teknik Talimatı, T.C. Tarım ve Köyişleri Bakanlığı Tarımsal Araştırmalar Genel Müdürlüğü, Ankara, $96 \mathrm{~s}$.

Anonim, 2005. Pratik Bağcılık, Manisa Tarım İl Müdürlüğü, Çiftçi Eğitim ve Yayım Şube Müdürlüğ̈̈, 2. Bask1, Manisa, 208 s.

Anonim, 2008. Zirai Mücadele Teknik Talimatları, Meyve ve Bağ Zararlıları, T.C. Tarım ve Köyişleri Bakanlığı Tarımsal Araştırmalar Genel Müdürlüğü, Cilt 4, Ankara, $388 \mathrm{~s}$.

Anonim, 2012. T.C. Tarım ve Köyişleri Bakanlığı İstatistik Veri A $\mathrm{g} 1$, http://iva.tarim.gov.tr/AppFolder/Raporlar [Erişim Tarihi: 23 Haziran 2014].

Anonim. http://www.ibp.gov.tr/pg/sektorpdf/tarim/kuru_uzum .pdf [Erişim Tarihi: 17 Mart 2014].

Anonim.

http://tuikapp.tuik.gov.tr/bitkiselapp/bitkisel.zul [Erişim Tarihi: 18 Mart 2014].

Anonim. 2016. http://faostat3.fao.org/faostatgateway/go/to/download/Q/QC/E [Erişim Tarihi: 16 Temmuz 2018].

Anonim, 2017. http://tuikapp.tuik.gov.tr/bitkiselapp/bitkisel.zul [Erişim Tarihi: 17 Temmuz 2018].

Anteliff, A.J., 1992. Taxonomy-The Grapevine as a Member of the Plant Kingdom (Ed.: B.G. Coombe and P.R. Dry, Viticulture Vol. 1 Resources: 107117), Hyde Park Press, Adelaide.

Ataç, Ö., Çevik, T. ve Zeki, C., 1987, Orta Anadolu Bölgesi Bağlarında Salkım Güvesi (Lobesia botrana Den. \& Schiff.) (Lepidoptera: Tortricidae)'nin Cinsel Çekici Tuzaklarla Mücadele Zamanının Saptanması ve $\mathrm{Bu}$ Tuzakların Erken Uyarıda Kullanılma Olanakları Üzerinde Araştırmalar, Türkiye I. Entomoloji Kongresi Bildirileri, 13-16 Ekim 1987, Ege Üniversitesi Atatürk Kültür Merkezi, Bornova, İzmir, Entomoloji Derneği Yayınları, No: 3, s. 119-128.

Ataç, Ö., Bulut, H., Çevik, T., 1990. Salkım Güvesi (Lobesia botrana Den. \& Schiff.)'ne Karşı Bacillus thuringiensis'in Tek Başına ve Carbaryl'in Düşük Dozu ile Birlikte Etkisinin Araştırılması, Türkiye II. Biyolojik Mücadele Kongresi, 26-29 Eylül 1990, Ankara, s. 127-135.

Bulduk, S., 1986. Üzüm ve Üzümden Yapılan 
Besinlerin Beslenmemizdeki Yeri ve Önemi, Tarım Orman ve Köyiş. Bak. Dergisi (TOK), Sayı: 3, Ankara.

Eltem, R., Aksoy, U., Altındişli, A., Sarıgül, N., Taşkın, E., Aşkun, T., Ateş, M., Meyvacı, B., Arasıler, Z., Turgut, H., Kartal, N., 2003. Ege Bölgesi'nde Çekirdeksiz Kuru Üzümlerde OTA Oluşumunun Belirlenmesi, I. Ulusal Mikotoksin Seтроzуuти, 1819 Eylül, İstanbul, 54-59.

İlter, E., 1975. Çekirdeksiz Üzüm Bağlarında Telli Goble Terbiye Sisteminin Yapılışı ve Bağların Şarjı, Bitki, 2 (4): 411-491.

İyriboz, N., 1938. Bağ Hastalıkları, Ziraat Vekaleti Neşriyatı, Umumi Sayı: 323, Ziraat Hastalıkları, Sayı: 2, Neşriyat Müdürlüğü, Ankara.

Kacar, N., 1982. Ege Bölgesi Koşullarına Uygun Bazı Üzüm Çeşitlerinde, Salkım Güvesi (Lobesia botrana Den. \& Schiff.) (Lep.: Tortricidae)'nin Zararı Üzerinde Gözlemler, Türk. Bit. Kor. Derg., 6: $105-$ 109.

Kaplan, C., Çınar, M., 1998. Güneydoğu Anadolu Bölgesi Bağlarında Ana ve Ekonomik Öneme Sahip Zararlılar ile Yararlıların Yıllık Popülasyon Değişimleri ve Zararlıların Mücadeleye Esas Kritik Biyolojik Dönemlerinin Saptanmas1, Diyarbakır Zirai Mücadele Araştırma Enstitüsü, Meyve ve Bağ Zararlıları Alanında Yayınlar (Yayınlanmamış, Nihai Rapor).

Karabulut, A., Demirel, N., 2014. Manisa İli Bağ Alanlarında Salkım Güvesi (Lobesia botrana Den. \& Schiff.) (Lepidoptera: Tortricidae)'nin Popülasyon Yoğunluğu ve Zarar Oranının Belirlenmesi, Türkiye V. Bitki Koruma Kongresi, 3-5 Şubat 2014, Antalya, s. 9.

Karadağ, S., Aslan, K. A., Akgün, A., Arpac1, S., Sarpkaya, K., Doğruer, K. N., Çalışkan, M., 2011. Organik Üzüm Yetiştiriciliği Organik Tarım Araştırma Sonuçları, Tarım ve Köyişleri Bakanlığı, Tarımsal Araştırmalar Genel Müdürlügü, Ankara, s. 43-50.

Kısakürek, Ö.R., 1972, Güney Anadolu Bölgesi Bağlarında Salkım Güvesi (Lobesia botrana Den. \& Schiff.)'nin Yayılış Alanı, Bulaşma Oranı, Parazit ve Predatörleri Üzerinde Ön Çalışmalar, Bitki Koruma Bülteni, 12 (3): 183-186.

Kovanc1, B., Türkmen, C., Kumral, N.A., 2005. İznik (Bursa) İlçesindeki Bağlarda Zararlı Salkım Güvesi [Lobesia botrana Den. \& Schiff. (Lep.: Tortricidae)]'nin Ergin Popülasyon Dalgalanmasi Üzerinde Araştırmalar, 6. Türkiye Bağcllık Sempozyumu, 19-23 Eylül 2005, Tekirdağ, Cilt: 1, 289-296 s.

Maçan, S., 1984. Güneydoğu Anadolu Bölgesi'nde Bağlarda Zarar Yapan Böcek Türleri, Önemlilerinin Tanımları, Yayılışları ve Ekonomik Önemleri Üzerine İncelemeler, Zirai Mücadele ve Zirai Karantina Genel Müdürlüğü, Yayın No 3: 47 s.
Mamay, M., Çakır, A., 2014. Şanlıurfa Merkez ilçe bağlarında Salkım güvesi [Lobesia botrana Denis \& Schiffermüller (Lepidoptera: Tortricidae)]'nin ergin popülasyon değişimi ve bulaşma oranının belirlenmesi. Bitki Koruma Bülteni, 54(2): 103-114.

Önçağ, G., 1975. Ege Bölgesi'nde Salkım Güvesi (Lobesia botrana Den. \& Schiff.)'nin Tanınmas1, Yayılışı, Biyolojisi, Zararı, Doğal Düşmanları ve Kimyasal Savaş İmkanları Üzerine Araştırmalar, T.C. Gıda Tarım ve Hayvancılık Bakanlığı, Zirai Mücadele ve Zir. Karantina Genel Müd. Araştırma Serisi, Teknik Bülten No: 26, İzmir, $68 \mathrm{~s}$.

Özbek, H., Güçlü, Ş., Hayat, R., Yıldırım, E., 1995. Meyve, Bağ ve Bazı Süs Bitkileri Zararlıları, Atatürk Üniversitesi. Ziraat Fak. Yayınları, Erzurum, $357 \mathrm{~s}$.

Özpınar, A., Albayrak, A., Görür, S.E., 2004. Çanakkale İli Bağ Alanlarında Salkım Güvesi [Lobesia botrana Den. \& Schiff. (Lepidoptera: Tortricidae)]'nin Popülasyon Gelişmesi ve Döl Sayısının Belirlenmesi, Türkiye I. Bitki Koruma Kongresi Bildiri Özetleri, 08-10 Eylül 2004, Samsun, $101 \mathrm{~s}$.

Öztürk, N., Acıöz, S., 2010. Tarsus (Mersin) Bağlarında Zararlı Salkım Güvesi [Lobesia botrana Den. \& Schiff. (Lepidoptera: Tortricidae)]'nin Ergin Popülasyon Değişimi, Bitki Koruma Bülteni, 2010, Mersin, 50(3): 111-120 s.

Öztürk, N., Şahin, Y., 2013. İslâhiye (Gaziantep) Bağlarında Salkım Güvesi [Lobesia botrana Den. \& Schiff. (Lepidoptera: Tortricidae)]'nin Ergin Popülasyon Değișimi, Alatarım Cilt 12 (1): 49-55 s.

Ringot, D., Chango, A., Schneider, Y.J., Larondelle, Y., 2006. Toxicokinetics and Toxicodynamics of Ochratoxin A, an Update, Chemico-Biological Interactions, 159: 18-46.

Saeidi, K., Kavoosi, B., 2011. Seasonal Flight Activity of the Grape Berry Moth, Lobesia botrana Den. \& Schiff. (Lepidoptera: Tortricidae) in Sisakht Region, Iran, African Journal of Agricultural Research, 6 (15): 3568-3573.

Sipahi, R., 1956. Idiocerus stali Fieb. ve Polychrosis botrana Schiff. Yaşayışı ve Mücadelesi, Gaziantep Zirai Araştırma Enstitüsü.

Şekerden Çağlar, Y., 2009. Hatay İli Bağ Alanlarındaki Zararlılar, Yayılışları, Parazitoit ve Predatörler ile Lobesia botrana Den. \& Schiff. (Lepidoptera: Tortricidae)'nın Popülasyon Gelişmesinin Belirlenmesi, Çukurova Üniversitesi Fen Bilimleri Enstitüsü, Bitki Koruma Anabilim Dalı, Doktora Tezi, Adana, $126 \mathrm{~s}$.

Westwood, M.N., 1993. Temperate-Zone Pomology, Physiology and Culture, Timber Press Inc. Portland, Oregon, $523 \mathrm{p}$.

Winkler, A.J., Cook, J.A., Kliewer, W.M., Lider, L.A., 1974. General Viticulture Univ. Calif. Press. Berkeley and Los Angeles, $710 \mathrm{p}$. 